zones of operations. In the current number of L'Anthropologie (47, 5-6) a note is published from the Abbé Breuil to M. R. Verneau, in which it is stated that Prof. H. Obermaier has been informed by a journalist that the famous cave of Altamira, in the neighbourhood of Santander, the best known and most important of the caves, had suffered no serious injury, although it had given shelter to some hundreds of refugees and the house of the guide had been occupied by an officer of the Red staff. Alcade del Rio also is informed that the same is true of the other caves with paintings of the Cantabrian Pyrenees. On the other hand, M. Verneau is told that the greater part of the archæological collection formed by Sen. Perez de Barradas and housed in the Municipal Museum of Madrid, had been broken up. News of the fate of the important paintings in the province of Teruel in eastern Spain will be awaited with no little anxiety.

\section{Palestine Archæological Museum}

THE Palestine Archæological Museum in the newly erected buildings at the north-eastern corner of the city of Jerusalem was opened to the public on January 13, the ceremony, which was to have taken place on January 11 in the presence of the High Commissioner, having been cancelled, owing to the murder of Mr. J. L. Starkey on the previous evening, when on his way to Jerusalem in order to be present. The cost of erecting the buildings has been met in part by a gift of two million dollars to the Government of Palestine by the late Mr. John D. Rockefeller. The site of ten acres, of which the buildings occupy one quarter, was provided by the Government. The architect was Mr. Austen St. B. Harrison. The Museum consists of a central rectangular block, flanked on north and south by buildings around open courts. In addition to the exhibition halls, open to the public, which will house the more striking and important exhibits, galleries are provided for the material which will be accessible to students, while in the basements provision has been made for housing archæological material from excavations and other sources, pending its allocation and distribution. Provision is also made for staff accommodation and library, the latter already consisting of ten thousand volumes, and space being reserved for a further thirty thousand. The Museum will cover the pre-, protoand historic periods, including the Roman, Byzantine and Arab antiquities of Palestine down to A.D. 1700. Among the antiquities now on view are the Galilee skull, the first Neanderthal skull to be found in Palestine, the remarkable collection of prehistoric pottery dating from the Stone Age to the close of the Canaanitish period, and the ivories from the palace of Ahab in Samaria, discovered in the excavations of 1933-35, which are among the most striking objects of æsthetic interest as yet found in Palestine.

\section{Further Exploration of Tell Duweir, Palestine}

APPREHENSION has been felt among archæologists lest the further exploration of Tell Duweir, the Biblical Lachish, should have to be abandoned, owing to the murder of Mr. J. L. Starkey, the director of the Marston-Wellcome Archæological Expedition to the Near East, by whom the mound was being excavated. The death of Mr. Starkey is universally regarded as an irreparable loss to Palestinian studies; but the blow would have been even heavier had it not been possible to continue work on this important site, which has already provided so much valuable material bearing on the interpretation of more than one crucial period in the history of the country and its cultural development. This fear has now been allayed by the announcement that the excavation will continue, at any rate for the present. Arrangements have been made by the High Commissioner for it to be carried on under the supervision of $\mathrm{Mr}$. Lankester Harding, who was recently appointed director of antiquities in Transjordania. Mr. Harding was Mr. Starkey's principal assistant in 1932-36. $\mathrm{He}$ is, therefore, not only well acquainted with the character of the site and the lie of its stratification, but also-and this is of no little importance-he is thoroughly familiar with the scheme of operations, which Mr. Starkey had plotted out in relation to the importance of the areas to be excavated, so far as this could be gauged in advance.

\section{Indian Universities and Nationalism}

THE annual Patna convocation lecture was delivered on November 27 by the vice-chancellor of the parent university of Calcutta, Mr. S. P. Mukherjee. The lecturer, although disclaiming for himself the qualifications of a historian, declared that Indian universities should saturate their alumni with the lessons of Indian history and civilization, and took as his principal theme an interpretation of Indian history coloured to stimulate the "ever-increasing vitality of Indian nationalism" with somewhat bitter references to present "bondage" and "a subject race and the power that wants to hold it in its leading strings". It seems regrettable, though not surprising, that the Indian universities should under the new constitution allow themselves to be used for the purposes of political propaganda. Lord Willingdon recently remarked that Indian politicians used to believe we were not sincere in wanting to help them in their advance towards responsible government but that they trust us now. No such change of heart seems to have been experienced by Mr. Mukherjee.

\section{Earthquake Records at De Bilt}

Dr. E. VAN EVERDINGEN's twenty-second report on the work of the seismological station at $\mathrm{De}$ Bilt continues, for the year 1934, the useful lists in its predecessors (K. Nederl. Meteor. Inst., No. 108; 1936). The station lies about five miles north-east of Utrecht and is provided with horizontal and vertical Galitzin seismographs in addition to Wiechert and Bosch seismographs. The report contains the times as recorded at De Bilt of the different phases of 487 earthquakes, and in most cases gives also useful details on the position of the epicentre, as determined by the records at different observatories, the places at which the earthquake was felt and the intensity at them when known. 